\title{
PENTINGNYA KOMUNIKASI IMAN MELALUI DISKURSUS IMAN DI DUNIA DIGITAL
}

\author{
Rafael Yohanes Kristianto
}

\begin{abstract}
Abstrak:
Fast development in science and technology provides human beings an advancement in all sectors, especially in industrial sector, health, and economics and social. The advancement also happens in information technology, resulting practicality in communicating with others without being limitted by distance and time. In this kind of situation, Church, as the part that cannot be seperated from the world, is also called to be involved in the information technology advancement and through it proclaim its mission: to proclaim God's Kingdom to all people. The result of the research shows that communication formed in "Katolistitas" sets readers free from the darkness of not having enough understanding about faith into their independence: the truth in life that comes from Jesus Christ, The Way, The Truth, and The Life. This research aims to gather diversity into the unity that brings people to the true fraternity. Forms a union that is called communicatio and builds communio. This commmunio finally unites them in "Katolisitas" community and communio of God's Kingdom is formed. Communication is also enhanced as the fruit of the Holy Spirit in the Church.
\end{abstract}

\section{Kata-kata Kunci:}

kemajuan iptek, komunikasi, media komunikasi digital, pewartaan Kerajaan Allah, dialog iman, diskursus iman, communio, katolisitas

\section{PENDAHULUAN}

Derasnya informasi yang bisa didapatkan pada zaman ini merupakan salah satu ciri dari kemajuan teknologi informasi dan akses internet yang semakin mudah dijangkau. Kemudahan tersebut semakin menjadikan orang mudah mendapatkan informasi dan berita dari segala penjuru dunia dalam waktu yang relatif singkat. Namun, di tengah derasnya informasi yang muncul, orang diharuskan lebih selektif lagi dalam menyaring segala informasi dan lebih cermat dalam menentukan sumber yang diperoleh dan dapat dipertanggung jawabkan.
Ada banyak juga website-website yang menyediakan sumber informasi ilmiah dan terpercaya yang disediakan oleh instansi dan institusi yang memiliki misi untuk memajukan dan mendidik orang-orang yang haus akan ilmu dan pengetahuan.

Dalam dunia virtual itu, budaya untuk saling berbagi atau share pengetahuan dan informasi menjadi sangat kuat. Budaya saling berbagi ini menjadi salah satu kekuatan positif yang bisa memperkaya para pengguna lainnya dan bisa membentuk komunitas yang saling peduli satu sama lain. Namun, tantangan yang ada di dalamnya 
adalah bagaimana benar-benar menjadi inklusif: dengan demikian mereka memperoleh manfaat dan peran serta penuh dari orang-orang beriman yang ingin berbagi amanat Yesus dan nilai martabat manusia yang dikemukakan melalui pengajaran-Nya. Kaum beriman semakin menyadari bahwa kalau Kabar Baik tidak diperkenalkan dalam dunia digital, ia akan hilang dalam pengalaman banyak orang yang menganggap ruang eksistensial ini penting. ${ }^{1}$ Lingkungan digital bukanlah sebuah dunia paralel atau murni virtual, tetapi merupakan bagian dari pengalaman keseharian banyak orang teristimewa kaum muda. Jejaring sosial adalah hasil interaksi manusia akan tetapi pada gilirannya, ia memberikan bentuk baru terhadap dinamika komunikasi yang membangun relasi: oleh karena itu pemahaman yang mendalam tentang lingkungan ini merupakan prasyarat untuk suatu kehadiran yang bermakna.

Gereja dalam melaksanakan misi pewartaannya juga menjadi salah satu institusi yang ikut berperan dalam membagikan kabar sukacita kepada dunia, yaitu kabar keselamatan bagi seluruh umat manusia. Misi pewartaan Gereja itu terwujud melalui jejaring sosial dan website-website yang dibuat oleh Gereja dalam rangka mengkomunikasikan ajaran Gereja kepada umatnya, sebagai contoh: www.vatican.va(Vatikan); www.catholicforum.com dan www.catholic. org; (Amerika Serikat); www.ffnfuncity.de (Jerman); www.katolisitas.org, www.imankatolik.or.id, dan www.ekaristi.org (Indonesia). Dalam penulisan ini, penulis mencoba memfokuskan pada proses komunikasi iman, interaksi dan diskursus yang terjalin dalam katolisitas.org. Mengapa katolisitas.org? Penulis memfokuskan pada website www.katolisitas.org karena di sana ruang tanya-jawab yang disediakan oleh website itu kepada para anggotanya lebih banyak dan proses interaksi serta diskursus itu pun terjadi secara kontinyu dan berkesinambungan serta ditanggapi secara serius dan ilmiah oleh para pengasuhnya, yang notabene, para pengasuhnya ahli dalam bidangnya masing-masing.

\section{DEFINISI KOMUNIKASI}

\section{Komunikasi dari Sudut Ilmu Komunikasi}

Definisi komunikasi sangat bergantung pada perspektif mana yang hendak dijadikan sebagai kerangka acuan. Komunikasi adalah sebuah proses yang dinamis. Komunikasi sebagai suatu proses yang dinamis selalu berubah dan tidak pernah selesai karena ia kaya akan makna. ${ }^{2}$ Komunikasi berasal dari akar kata communis (Latin). Dari kata kerja communicare yang berarti masuk ke dalam relasi, menjalin ikatan atau membuat menjadi umum. Communicatio adalah bentuk kata benda dari communicare, yang berarti pemberitahuan atau hal mengambil bagian dalam. Orang yang mengambil bagian dalam atau yang terlibat atau yang berkomunikasi adalah communicator. $^{3}$

Tujuan intrinsik komunikasi adalah untuk merangkul segala yang berbeda-beda ke dalam satu gelombang/wadah yang sama. Dengan kata lain komunikasi pada hakekatnya bertujuan untuk meciptakan persatuan dengan memperhatikan intisari yang terkandung dalam segala bentuk perbedaan yang ada. Karena itu komunikasi harus merupakan proses yang berlangsung terus dari yang bersifat pribadi kepada yang lebih umum dan sebaliknya. Sehingga pada akhirnya tujuan profetis komunikasi, yaitu transformasi manusia baik secara pribadi maupun bersama-sama.

Komunikasi, baik secara spotan maupun terencana selalu memiliki tujuan tertentu. Secara umum tujuan komunikasi dapat diketegorikan ke dalam empat jenis. Pertama, komunikasi bertujuan untuk terjadinya perubahan pendapat (opinion change) seseorang. Kedua, komunikasi juga bertujuan untuk mempengaruhi dalam rangka perubahan sikap (attitude change) seseorang. Ketiga, komunikasi bertujuan untuk merangsang seseorang untuk berbuat sesuatu, yaitu dalam rangka perubahan perilaku (behaviour change). Keempat, komunikasi bertujuan untuk memperbaiki keadaan sosial dalam rangka perubahan sosial (social change). ${ }^{4}$ 


\section{Komunikasi dari Sudut Pandang Filosofis menurut Jürgen Habermas}

Jürgen Habermas menolak anggapan Karl Marx bahwa manusia menciptakan diri dalam pekerjaan. ${ }^{5}$ Akan tetapi, menurut Habermas kerangka konseptual ini tidak memadai. Pekerjaan adalah sikap manusia terhadap alam. Ada subjek yang aktif yaitu manusia, dan ada objek yang pasif yaitu alam. Hubungan antar manusia adalah hubungan antara dua subjek yang sama kedudukannya, dua-duanya baik aktif maupun pasif. ${ }^{6}$ Rasionalitas pekerjaan adalah rasionalitas sasaran.Pekerjaan itu rasional apabila sasaran yang sudah ditetapkan sebelumnya. Tetapi komunikasi bersifat lain. Komunikasi bukan monologis, melainkan dialogis, bukan individualistis, melainkan sosial. Dalam komunikasi para partisipan mengkoordinasikan rencana tindakan mereka, bukan masing-masing partisipan memakai partisipan lain untuk mencapai tujuan mereka masing-masing, itu tak lain adalah tindakan strategis. Dalam komunikasi yang terjadi: Masing-masing partisipan mengambil alih peran partisipan yang lain. "Dengan mengambil alih peran orang lain, saya dapat merefleksikan diri saya sendiri dan dengan demikian mengarahkan proses komunikasi saya". ${ }^{7}$ Sebuah komunikasi itu rasional apabila saling pengertian tercapai di antara kedua belah pihak. Di sanalah terjadi rasionalitas komunikatif. ${ }^{8}$

Akan tetapi, apakah tindakan komunikatif itu mungkin? Ataukah semua hubungan antar manusia sudah bersifat strategis belaka? Ya, tindakan komunikatif itu mungkin, bahkan tindakan strategis hanya dapat berhasil jika sudah ada komunikasi sungguh-sungguh, itu diperlihatkan Habermas dengan analisis terhadap medan utama komunikasi, yaitu bahasa. Menurut Habermas, bahasa adalah tempat manusia senantiasa sudah tahu apa yang dimaksud dengan rasionalitas dan kebebasan. ${ }^{9}$ Gagasan dasar Habermas adalah bahwa kita hanya dapat mau berbicara karena kita sudah mengetahui arti sebuah komunikasi yang tidak terdistorsi.

Menurut Habermas, siapa pun yang masuk ke dalam suatu pembicaraan, selalu sudah mengandaikankeberlakuan empat klaim ${ }^{10}$ : Kejelasan (understandability: aku mengungkapkan diri dengan jelas sehingga apa yang mau dikatakan dapat dimengerti), kebenaran (truth: aku mau menyampaikan sesuatu), kejujuran (truthfulness: aku mau mengungkapkan diriku), dan ketepatan (rightness: omonganku harus cocok dengan norma-norma komunikasi, kita harus mau mencapai saling pengertian). Secara sederhana: supaya komunikasi apa pun dapat berhasil orang harus berbicara dengan jelas, benar, jujur, dan tepat. Apabila saya menyangkal salah satu saja dari empat tuntutan itu, maka komunikasi tidak akan jalan. Dalam situasi ini memperlihatkan bahwa orang yang mau berkomunikasi selalu sudah mempunyai pengertian intuitif tentang rasionalitas komunikatif. Ia selalu sudah dapat membedakan antara sikap rasional dan tidak rasional. Tidak rasional adalah sikap yang menyangkal salah satu dari empat klaim itu.

Begitu pula keberhasilan komunikasi tidak dapat dipaksakan.Komunikasi mengandaikan empat klaim tadi dan empatempatnya tidak dapat dipaksakan atau direkayasa. Komunikasi itu kebal kekuasaan. Misalnya saja, sang raja yang tersesat waktu berburu rusa menanyakan jalan ke Majapahit pada seorang petani. Jika si petani saking takutnya tidak mengerti apa yang ditanyakan atau tidak dapat berbicara dengan jelas, maka petani pun tidak dapat menjawab pertanyaan dengan betul. Komunikasi hanya berhasil dalam hubungan yang bebas dan berkedudukan sama.

\section{Komunikasi dari Sudut Pandang Teologi}

Kekristenan merupakan agama komunikasi sebab Allah pada hakikat-Nya yang paling dalam adalah misteri komunikasi diri Allah. ${ }^{11}$ Seluruh karya penciptaan, penebusan, dan pengudusan merupakan perpanjangan dari prosesi batin di dalam Allah Tritunggal. Seperti terdapat dalam Surat Rasul Paulus kepada orang-orang Ibrani: "Setelah pada zaman dahulu Allah berulang kali dan dalam pelbagai cara berbicara kepada nenek moyang kita dengan perantaraan nabinabi, maka pada zaman akhir ini Ia telah berbicara kepada kita dengan perantaraan Anak-Nya, yang telah Ia tetapkan sebagai yang berhak menerima segala yang ada. 
Oleh Dia Allah telah menjadikan alam semesta" (Ibr 1:1-2). Pelayanan dan misi Gereja adalah mengkomunikasikan Kabar Baik tentang keselamatan serta cinta kasih Allah kepada makhluk ciptaan-Nya. Gereja perlu melanjutkan komunikasi tersebut dalam rengkuhan Tritunggal Mahakudus, yakni pewahyuan dan penjelmaan komunikasi Allah ke dalam "sini dan kini"-nya kehidupan sehari-hari melintasi abad demi abad. ${ }^{12}$

Franz-Josef Eilers mengutip Gisbert Greshake, seorang teolog Jerman, memperlihatkan bahwa sudah dalam sejarah teologi Kristen sendiri, yang bermula dengan Konsili Nicea, Allah dilihat sebagai suatu "kesatuan relasional" yang berkomunikasi dalam diri-Nya sendiri dan akhirnya berkomunikasi kepada ciptaan-Nya. ${ }^{13}$ Hingga akhirnya Eilers mengutip Greshake, menyimpulkan berdasarkan berbagai teori dan perkembangan komunikasi modern, yaitu bahwa "Allah itu sendiri adalah komunikasi. Ia mengkomunikasikan diri-Nya kepada dunia dan memampukan dunia agar bisa berkomunikasi sehingga ciptaan dalam komunikasinya itu menjadi serupa dengan Allah dan menggapai persekutuan paling mesra dengan-Nya."14 Berdasarkan pandangan di atas, maka komunikasi dalam teologi dilihat sebagai sebuah dimensi hakiki untuk seluruh teologi. Franz-Josef Eilers mengutip Every Dulles memandang bahwa seluruh teologi merupakan komunikasi diri Allah kepada manusia. ${ }^{15}$

Berdasarkan pada pengamatan antara komunikasi media dan komunikasi iman, maka dapat disimpulkan beberapa perbedaan berikut:

\begin{tabular}{|c|c|}
\hline Komunikasi iman & Komunikasi media \\
\hline $\begin{array}{ll}\text { - } & \text { Sebuah misteri iman } \\
\text { - } & \text { Injil yang esa, abadi } \\
\text { dengan kesinambungan } \\
\text { - } & \text { Kesatuan dan } \\
& \text { perpaduan } \\
\text { - } & \text { Rahmat baru, berkat- } \\
\text { berkat rohani }\end{array}$ & $\begin{array}{ll}\text { - } & \text { Investigatif } \\
\text { - } & \text { Selalu baru, segera } \\
& \text { berlalu, "bergolak" } \\
\text { - } & \text { Beda pendapat, konflik } \\
\text { - } & \text { Melaporkan hal-hal } \\
& \text { yang kasatmata secara } \\
& \text { selektif }\end{array}$ \\
\hline $\begin{array}{l}\text { Otoritas hierarkis, } \\
\text { otoritas Kristus } \\
\text { Majemuk dan berbelit- } \\
\text { belit dalam pengajaran }\end{array}$ & $\begin{array}{ll}\text { - } & \text { Kriteria "demokratis" } \\
\text { - } & \text { Lapar akan "cerita- } \\
\text { cerita"- singkat, } \\
\text { sederhana, memikat }\end{array}$ \\
\hline
\end{tabular}

Berdasar pada sudut pandang Trinitaris, Allah dilihat sebagai Allah yang mengkomunikasikan diri-Nya sendiri. Bapa, Putera, dan Roh Kudus berkomunikasi satu sama lain dalam gerak batiniah Allah Tritunggal. Bernard Häring dengan jitu telah melukiskan komunikasi batiniah sebagai berikut ${ }^{16}$ :

Yesus, Firman yang menjelma, mewahyukan kehidupan ilahi sebagai komunikasi, pembagian diri.Yesus berdoa, 'Segala milik-Ku adalah milik-Mu dan milik$\mathrm{Mu}$ adalah milik-Ku' (Yoh 17:10).Ia membagi diri-Nya dan segala kebenaran yang muncul dari sharing total antara Bapa dan Putera dan Roh Kudus. Roh Kudus adalah sharing, komunikasi. Apabila Ia datang, yaitu Roh Kebenaran, Ia akan memimpin kamu ke dalam seluruh kebenaran; sebab Ia tidak berkata-kata dari diri-Nya sendiri, tetapi segala sesuatu yang didengar-Nya itulah yang akan dikatakan-Nya' (Yoh 16:13).

Komunikasi merupakan unsur konstitutif dalam misteri Allah.Masing-masing ketiga Pribadi ilahi memiliki segala sesuatu yang baik, segala sesuatu yang benar, segala sesuatu yang indah, namun dalam pola komunio dan komunikasi.Penciptaan, penebusan dan komunikasi muncul dari misteri ini, dan sasaran akhirnya ialah untuk menarik kita, berkat komunikasi itu sendiri, ke dalam persekutuan dengan Allah.dengan menciptakan kita seturut gambar dan rupa-Nya, Allah menjadikan kita peserta komunikasi-Nya yang kreatif lagi membebaskan dalam persekutuan, melalui persekutuan dan demi persekutuan.

Mengapa kita sebagai makhluk insani mampu berkomunikasi? Karena Allah Tritunggal yang berkomunikasi itulah yang telah menciptakan kita seturut gambar dan rupa-Nya. Karena Allah adalah Allah yang berkomunikasi, maka kita pun (manusia) mampu berkomunikasi.

\section{WAJAH KATOLISITAS DI DUNIA DIGITAL}

Website katolisitas merupakan salah satu website resmi Gereja Katolik Indonesia yang berdiri secara mandiri dan tidak berada di bawah naungan organisatoris otoritas Gereja Katolik seperti Keuskupan ataupun Konferensi Waligereja Indonesia ataupun 
paroki atau juga Ordo/tarekat religius. Kendati tidak berada di bawah naungan otoritas Gereja Katolik, website ini banyak dibimbing oleh para pastor/romo yang memiliki perhatian pada bidang pewartaan dan iman Katolik. Seperti sudah dicantumkan di atas dalam timeline perkembangan katolisitas, keterlibatan para pastor/romo dan juga awam yang ahli di bidangnya masing-masing memberi warna dan ikut memperkaya khazanah iman para pembaca katolisitas. Dalam struktur yang terjalin di katolisitas, gambaran Gereja yang merupakan tubuh Kristus menjadi semakin nyata berkat kesatuan antar timkatolisitas yang tampak dari sifatnya yang saling bekerja sama, melengkapi dan menyempurnakan satu sama lain dalam rangka pewartaan Kabar Gembira kepada seluruh dunia.

Katolisitas sebagai sebuah website resmi Gereja Katolik memiliki ciri khas yang berbeda dengan website rohani Katolik lainnya, yaitu: a) memberikan ruang yang luas untuk berdiskusi mendalam tentang iman Katolik bagi orang-orang Katolik dan orang non-Katolik yang sedang berupaya mencari kebenaran, b) memberikan bimbingan yang berkesinambungan kepada orang-orang yang sedang mencari kebenaran dalam hidupnya (baik bagi orang Katolik maupun orang non-Katolik, ataupun orang Katolik yang pernah meninggalkan imannya tetapi kembali lagi ke dalam pangkuan Gereja Katolik) khususnya berdasarkan pada iman Katolik dalam bentuk tanya-jawab dan diskusi dalam kolom tanya-jawab, c) Terdapat pojok doa yang memiliki tujuan untuk menjalin persekutuan doa saudara seiman via website katolisitas dan mendoakan orangorang yang membutuhkan doa yang dipimpin oleh Rm Paulus Kristianto P.S. O.Carm bersama dengan 8 orang tim doanya, d) Memiliki arsip dokumen-dokumen Gereja yang lengkap dan juga artikel-artikel tentang iman katolik yang terkait dengan fenomena zaman modern ini. Sebagai seorang pengamat dunia internet, penulis melihat bahwa website katolisitas ini bisa dikatakan sebagai salah satu website lokal yang cukup lengkap dan sistematis dalam menyajikan informasi dan pengetahuan iman, mumpuni untuk membimbing serta mengarahkan para pembacanya kepada kebenaran iman
Katolik dan juga sangat terbuka kepada penganut agama lain maupun orang asing di luar teritori Indonesia.

Dengan slogannya "Knowing and Loving Our Catholic Faith", katolisitas berusaha menampilkan wajah Gereja Katolik yang menuntun orang pada pemahaman iman Katolik yang mendalam dan komprehensif sehingga dengan mendasarkan iman pada pengetahuan yang utuh, orang bisa semakin mencintai iman Katoliknya dan semakin menghayatinya dalam hidup sehari-hari. Melalui slogannya itu, para pembaca yang terlibat diajak untuk beriman dengan disertai pemikiran akal sehat, sehingga iman yang dianutnya bukan merupakan iman yang buta, melainkan iman yang bisa dipertanggung-jawabkan berdasarkan pada pengetahuan dan akal budi manusia, dan tentu saja juga berakar pada tiga pilar Gereja Katolik (Kitab Suci, Tradisi Suci, dan Magisterium Gereja). Dalam hal inilah para pembaca diajak untuk menemukan imannya berdasarkan pada kebenarankebenaran yang diarahkan oleh Gereja sehingga ia dapat menemukan kebenaran sejati itu sendiri di dalam hidupnya, yang tak lain adalah Kristus sendiri, Sang Jalan, Kebenaran dan Kehidupan

\section{HASIL PENELITIAN}

\section{Katolisitas sebagai Sarana Komunikasi Menekankan pada Komunikasi yang Jelas, Tepat dan Mudah Dipahami}

Katolisitas sebagai sebuah media pewartaan iman bertekad untuk mewartakan ajaran dan iman Katolik kepada siapa saja yang berniat mencari kebenaran dan pengetahuan akan iman katolik dalam hidup. Berangkat dari tujuan itu, maka katolisitas memberikan banyak ruang mengenai informasi dan pengajaran iman Katolik yang dapat diakses oleh siapa pun, dan secara khusus katolisitas membuat suatu jaringan yang memungkinkan para pembacanya dapat eksploratif memperdalam pengetahuan imannya itu dengan membuat ruang tanya-jawab dan diskusi sehingga masingmasing anggotanya saling diperkaya satu sama lain. Melalui ruang tanya-jawab dan diskusi itu terjalinlah suatu diskursus yang saling memperkaya pengetahuan iman dan 
ajaran Gereja Katolik, dan tentu saja sebagai website resmi, katolisitas mengedepankan penggunaan bahasa yang jelas, tepat dan mudah dipahami (bahasa utama yang digunakan adalah bahasa Indonesia, namun kadang juga menggunakan bahasa Inggris karena terkait dengan artikel tertentu, atau terkait dengan member yang berasal dari negara tetangga).

Penggunaan bahasa Indonesia dalam dunia internet tidaklah selalu menggunakan bahasa Indonesia yang resmi dan sesuai dengan EYD (Ejaan yang Disempurnakan), melainkan menggunakan bahasa Indonesia yang santai dan kadang menggunakan ungkapan-ungkapan bahasa lisan dan bahasa slang, namun ungkapan dan maksud dari pesan yang disampaikan masih dapat ditangkap dan dipahami. Faktor kejelasan yang penulis maksud disini yaitu unsur penyampaian pesan yang diungkapkan di dalam dialog itu dapat diterima oleh pihak kedua (pengasuh katolisitas sebagai penyedia sarana dialog atau pembaca/ member yang berinteraksi dengan pengasuh katolisitas dalam dialog tersebut), atau ketiga (member katolisitas lainnya yang ikut serta menanggapi komentar dari ruang tanya-jawab katolisitas) sehingga terjadi suatu interaksi dari dua arah, bukan monolog. Faktor ketepatan yang penulis maksud yaitu unsur kesesuaian pembicaraan dengan topik yang sedang berlangsung dan tidak melebarnya pembicaraan ke pelbagai macam hal.Kedua faktor tersebut, yaitu kejelasan dan kesesuaian dalam komunikasi menjadi sangat penting karena sangat berperan untuk menunjang terjadi dialog yang interaktif dan terbuka sehingga tujuan dari komunikasi itu dapat tercapai.Berikut kami tampilkan hasil penelitian dalam tabel 1 mengenai komunikasi yang menggunakan bahasa yang jelas, tepat, dan mudah dipahami.

Tabel 1. Komunikasi yang menggunakan bahasa yang jelas, tepat, dan mudah dipahami (kejelasan\& ketepatan/understandability)

\begin{tabular}{|c|c|c|c|c|c|c|}
\hline \multicolumn{6}{|c|}{ Komunikasi yang jelas, tepat dan mudah dipahami (undestandability) } & \multirow{3}{*}{ Total } \\
\hline \multicolumn{4}{|c|}{ Member/pembaca yg menggunakan bahasa } & \multicolumn{2}{|c|}{$\begin{array}{c}\text { Pengasuh yg menggunakan } \\
\text { bahasa }\end{array}$} & \\
\hline $\begin{array}{c}\text { Jelas \& } \\
\text { tepat }\end{array}$ & $\begin{array}{c}\text { Jelas, tapi } \\
\text { kurang } \\
\text { tepat }\end{array}$ & $\begin{array}{c}\text { Kurang } \\
\text { jelas, tapi } \\
\text { tepat }\end{array}$ & $\begin{array}{l}\text { Tidak jelas } \\
\text { \& tidak tepat }\end{array}$ & $\begin{array}{c}\text { Jelas \& } \\
\text { tepat }\end{array}$ & $\begin{array}{l}\text { Kurang jelas, } \\
\text { tapi tepat }\end{array}$ & \\
\hline 988 & 97 & 30 & 118 & 563 & 8 & 1804 \\
\hline $79,74 \%$ & $7,92 \%$ & $2,52 \%$ & $9,82 \%$ & $98,57 \%$ & $1,43 \%$ & \\
\hline
\end{tabular}

Berdasarkan hasil penelitian, lebih dari tiga perempat member $(79,74 \%)$ yang menggunakan bahasa jelas dan dapat dimengerti dan dipahami oleh peserta diskursus di ruang tanya-jawab katolisitas. Dengan kata lain, penggunaan bahasa yang jelas dalam diskusi dan dialog di ruang tanyajawab katolisitas menjadi hal penting yang mendukung proses komunikasi dan dialog yang berkelanjutan. Sementara itu, kurang dari sepersepuluh member $(9,82 \%)$ menggunakan bahasa yang tidak jelas dan kurang dapat dipahami maksud dari pesan yang disampaikannya itu. Para member yang menggunakan bahasa yang tidak jelas ini merupakan para member yang menggunakan bahasa yang kasar dan berisi tentang sumpah-serapah karena pendapatnya tidak bisa diterima oleh yang lain. Member ini kalau dilihat indetitasnya merupakan member yang berasal dari agama yang lain, yang beraliran keras dan tidak bisa menerima pandangan agama lain dengan terbuka. Mereka ini selalu mengungkapkan pendapat sendiri dan kerap kali keluar dari konteks pembicaraan (out of context) dan selalu bertanya tentang hal yang sama, yang sudah pernah diungkap dalam pembicaraan sebelumnya, namun selalu meminta jawaban. Jawaban pun sudah diberikan oleh para 
pengasuh katolisitas dan juga dari member lainnya, tetapi karena jawaban itu tidak sesuai dengan pemikiran mereka (oknumoknum yang beraliran keras ini), maka mereka berbicara tidak jelas dan arahnya ke mana-mana.

Sisanya 7,92\% member itu berbahasa dengan jelas, namun tidak tepat. Artinya, mereka berdialog dengan terbuka dan berkomunikasi dengan jelas, namun bahasanya berbelit-belit dan kadang pembicaraannya melebar dan meluas. Sedangkan 2,52\% member berbahasa dengan kurang jelas, namun tepat. Artinya mereka berbicara hanya singkat-singkat saja dan kadang menggunakan bahasa slang (yang masih dapat dipahami) dan sesuai dengan pembicaraan yang terjadi. Sedangkan dari sudut para pengasuh katolisitas, 98,57\% para pengasuh katolisitas berbahasa jelas dan tepat dan $1,43 \%$ para pengasuh berbahasa kurang jelas dan tepat.

\section{Katolisitas sebagai Sarana Komunikasi Menekankan Kebenaran sesuai dengan Ajaran Gereja}

Katolisitas sebagai sebuah media komunikasi yang turut membantu Gereja Katolik menyebarluaskan ajaran Gereja Katolik tentu saja harus bertumpu pada kebenaran tentang ajaran Gereja Katolik Roma dan juga bertumpu pada norma moral yang berlaku di Indonesia secara khusus dan norma ketimuran bangsa Asia secara umum. Yang menjadi tantangan bagi media pewartaan di dunia internet yaitu banyaknya informasi yang muncul di dunia internet itu sendiri yang sumbernya kurang bisa dipertanggung jawabkan secara ilmiah dan biasanya bersifat subyektif.Salah satu ciri yang mewarnai dunia internet adalah budaya saling berbagi dan sharing informasi dan pengetahuan melalui internet.Dampak dari derasnya informasi dan pengetahuan yang bisa diakses dengan mudah melalui internet, menjadikan orang perlu memilah informasi tersebut dan berhati-hati untuk mempercayai sepenuhnya informasi dan pengetahuan tersebut, sebelum mengecek kebenarannya dan sumber yang digunakan. Nilai kebenaran inilah yang diusung oleh website katolisitas dalam menyajikan dan menyebarkan pewartaan ajaran dan iman
Katolik kepada semua orang. Sebab, berdasarkan pada tujuan utamanya yaitu membawa orang pada kebenaran sejati dalam hidup yaitu Yesus Kristus sendiri, maka sesuai dengan tujuan itu segala pewartaan dan bentuk komunikasi di website katolisitas berlandaskan pada kebenaran. Di sinilah katolisitas hendak menawarkan suatu nilai yaitu bahwa aku mau menyampaikan sesuatu yang telah kualami dan kuhidupi yaitu tentang kebenaran iman yang selama ini diimani oleh Gereja Katolik. Berikut kami tampilkan hasil penelitian dalam tabel 2 mengenai komunikasi yang didasarkan pada kebenaran ajaran Gereja Katolik dan kebenaran sesuai dengan norma setempat.

Tabel 2. Komunikasi yang didasarkan pada kebenaran ajaran Gereja Katolik dan Kebenaran sesuai Norma

\begin{tabular}{|c|c|c|}
\hline \multicolumn{2}{|c|}{$\begin{array}{c}\text { Komunikasi yang didasarkan pada } \\
\text { kebenaran (truth) }\end{array}$} & \\
\cline { 1 - 2 } $\begin{array}{c}\text { Member yang } \\
\text { berdialog berdasar } \\
\text { kebenaran }\end{array}$ & $\begin{array}{c}\text { Member yang } \\
\text { berdialog } \\
\text { tidak berdasar } \\
\text { kebenaran }\end{array}$ & Total \\
\hline 883 & 350 & 1233 \\
\hline $71,61 \%$ & $28,39 \%$ & $100 \%$ \\
\hline
\end{tabular}

Tiga perempat kurang sedikit dari member katolisitas $(71,61 \%)$ berusaha untuk berkomunikasi berdasarkan pada kebenaran yang sesuai dengan ajaran Gereja Katolik dan benar sesuai dengan norma moral dan adat ketimuran bangsa Asia (kesopanan, keramahan, keterbukaan menerima yang berbeda). Mereka ini dalam berkomunikasi bertolak pada pencarian kebenaran (dari sisi member) dan mau menerima komentar yang benar dan menerimanya dengan lapang dada jika itu agak bersinggungan dengan pendapat mereka pribadi. Kesediaan para member untuk menerima kebenaran inilah yang penulis lihat sebagai unsur keterbukaan berdialog dan menerima kebenaran itu dengan rendah hati kendati berbeda dengan pendapat mereka pribadi. Ini salah satu contoh member yang menjunjung kebenaran dalam dialognya:

Saudara yang dikasihi Tuhan Yang Maha Pengasih dan Penyayang, Cara pandang 
yang berbeda pasti hasilnya berbeda, saudara Muslim pasti berdasarkan Alquran dan hadis (yang sering kami dengar), sedangkan umat kristen juga katolik berdasarkan Alkitab, dan tegasnya untuk mengakui atau menyebut Allah Yahwe itu "Bapa" saja kalau tidak mendapatkan Roh Kudus tidak mungkin mampu dan mau memanggil Allah Pencipta itu Bapa, kalau saya yang percaya Yesus sebagai Tuhan dan juga yang disebut Dia itu: Alfa dan Omega, maka dengan Salib Kristus, saya belajar ber-positive thinking $(+)$, oleh sebab itu saya bisa memahami agama-agama lain yang tidak jarang kami jumpai sangat beda dengan apa yang kami imani, bahkan sesama umat katolik juga bisa ditemukan cara pandang yang belum sama, ini perlu proses iman yang tentu perlu waktu ada juga sebagai ujian, tapi sebagian manusia bisa merasakan bahwa Allah itu Kasih (kita perlu Allah bukan sebaliknya, maka Allah itu selalu memberi, bukan menghukum dalam arti bahwa segala ketidak taatan kita itu yang membawa kita kependeritaan). Silahkan saudara, sesama manusia mengimani sesuai dengan ajarannya masing-masing, yang penting kita saling mengasihi (memberi yang terbaik) sebab yang baik itu berasal dari Tuhan Yang Maha Pengasih dan Maha Penyayang. Semoga Rahmat dan Damai Sejahtera dari Allah Sang Maha Cinta memberikan pencerahan kepada kita semua. Amin (Djupri Susetyo dalam tema "Eli, Eli Lama Sabhaktani” pada 8 Mei $2013 @ 8: 18$ pm).

Tiga perempat kurang sedikit dari member katolisitas $(71,61 \%)$ inilah yang berani mencari kebenaran untuk menggali ajaran Gereja Katolik yang dipaparkan oleh katolisitas. Mereka ini juga biasanya bersikap sopan, ramah, dan terbuka terhadap member lainnya atau pun para pengasuh katolisitas. Sehingga dalam ruang tanyajawab itu terjadilah dialog dan komunikasi yang tulus dan keramahanjuga turut mewarnai dialog di ruang tanya jawab katolisitas.

Sementara itu, lebih dari seperempat member $(28,39 \%)$ berdialog dan berkomunikasi tidak mencari kebenaran berdasar pada ajaran Gereja Katolik, melainkan bersikukuh akan pendapat mereka pribadi atau pun pendapat kelompok mereka. Mereka ini biasanya berbicara berangkat dari pengetahuan yang text-book dan hanya berdasar pada teori atau sedikit informasi (tentang Gereja Katolik) dari orang lain. Mereka inilah yang biasanya berasal dari orang non-katolik yang berusaha mengkritisi iman Katolik berdasar pada apa yang mereka dengar atau baca (namun hanya setengah-setengah saja), dan berdasarkan pada informasi dan pengetahuan yang tidak lengkap itu, mereka berniat untuk melakukan dialog dalam ruang tanya-jawab, namun yang terjadi justru bukan dialog tapi debat kusir, sebab mereka tidak mau menerima pandangan yang berbeda dari pandangan mereka. Mereka biasanya memulai diskusi itu dengan pengandaian-pengandaian yang kadang agak dibuat-buat. Namun, ketika dialog itu berjalan "hangat", justru mereka malah menolak mentahmentah apa yang ditawarkan dan cenderung keras kepala karena mereka cenderung tertutup. Mereka ini juga biasanya menggunakan kata-kata yang tidak sopan dan sama sekali tidak ramah terhadap member lainnya dan juga pada para pengasuh katolisitas. Inilah salah satu contohnya:

Itu tulisan apa? Apa yang mau di mengerti... Mau bodoh seperti anda?....

Jadi menurut bapak Tuhan itu plin plan..... Tuhan tak sebodoh bapak....

Sebenarnya yang mana di bilang argumen.... Yang paling menonjol hanya artikel yang meyakinkan bahwa Yesus itu Tuhan.... Tidak ada penjelasan yang logis dan tidak ada ayat-ayat yang di wahyukan oleh Allah... terlebih ayat-ayat yang bapak tunjukan hanya hasil tulisan murid Yesus yang menghianati Yesus..

Apa bapak tidak tahu ajaran murni Yesus? Jangan di sembunyikan dong $>>>>>\ldots . .$.

Bapak orang munafik

Pertanyaan saya jika seandainya ajaran bapak salah........ (karena ini hanya merupakan "pengandaian", maka saya tidak perlu menjawab secara panjang lebar, karena yang namanya pengandaian belum tentu benar.) Jadi betul kan? Bapak tidak bisa menjawab......jadi bapak itu orang yang angkuh seperti paulus............. Jadi sekian trima kasih.......dialog terakhir.......... (arfandi dalam "apakah hukum taurat dibatalkan yesus” pada 18 des 2009 @9:37am) 
Kendati demikian, justru dalam keadaan itu orang diajak untuk memperdalam iman kekatolikannya dan memurnikan imannya itu berkat kehadiran mereka yang mengkritisi iman Katolik. Dengan melihat dialog yang alot dari member yang tertutup, di sanalah peneliti melihat bahwa kebenaran itu justru bisa terungkap ketika ajaran Gereja itu dibanjiri oleh berbagai pendapatpendapat "miring" (tidak benar), pendapat yang setengah-setengah (tidak utuh), dan pendapat yang mencoba melawan ajaran Gereja Katolik, namun di tengah dialog yang alot itu, ajaran Gereja Katolik tetap bisa menjawab semua keragu-raguan dengan suatu kepastian yang berdasarkan kebenaran pada Firman Tuhan dan ajaran resmi Gereja Katolik. Ajaran Gereja Katolik tetap berdiri teguh dengan jawaban yang penuh keramahan, kesopanan dan keterbukaan kepada yang lain. Peneliti juga kagum terhadap sikap yang ditunjukkan oleh para pengasuh yang selalu sabar, sopan, ramah, dan terbuka terhadap mereka yang beraliran keras dan ekstrim dari agama yang lain. Di dalam ruang tanya-jawab itu tampak begitu eksplisit mana nilai-nilai kebenaran yang sesuai dengan ajaran Gereja Katolik, dan mana yang tidak sesuai dengan kebenaran (artinya yang terus berpegang teguh pada pendapat pribadi atau kelompoknya sendiri) dan member yang lainnya yang bukan pengasuh juga bisa melihatmana kebenaran objektif yang sejalan dengan ajaran Gereja Katolik mana yang tidak sesuai dengan ajaran Gereja Katolik, dan akhirnya mereka pun bisa menemukan kebenaran itu sendiri dalam diri Kristus sendiri, Sang Kebenaran Sejati.

\section{Katolisitas Mengajak Orang untuk Menggali Dasar Iman Katolik berhadapan dengan Tantangan Zaman Modern}

Relativisme adalah problem terdalam pada masa kini. Semua itu terjadi karena semakin marak dan diterimanya budaya diktatoritas relativisme, tidak ada yang mutlak dan benar kecuali hanya "aku", dan diri sendiri ditempatkan sebagai tolok ukur terakhir, sebagaimana diuraikan oleh Krispurwana Cahyadi mengutip pemikiran Josep Ratzinger. ${ }^{17}$ Kristus sebagai ukuran akan segala hal, diganti oleh cinta, kepentingan dan kehendak diri. Padahal sesungguhnya,
Yesus Kristus adalah tolok ukur serta tatapan kemanusiaan sejati sehingga iman yang dewasa bukanlah iman yang mengikuti arus mode dan temuan-temuan terbaru, melainkan iman yang berakar mendalam dalam persahabatan serta kesetiaan pada Kristus. Maka, seharusnya orang Kristiani sejati sepatutnya meletakkan keyakinannya pada iman yang berakar dari Kristus bukannya mengikuti trend dan meletakkan keyakinan imannya pada temuan-temuan yang ditemukan oleh pihak-pihak yang mengusung pembaruan. Nilai inilah yang coba ditawarkan oleh katolisitas dalam menanggapi begitu pesatnya perkembangan zaman modern ini. Maka dari itu refleksi iman dan pengetahuan iman yang diterangkan dalam katolisitas, disajikan secara utuh, tidak terpotong-potong, dan kontinuitas dengan pengenalan keseluruhan perjalanan historisitas tradisi dalam Gereja. Tentunya, katolisitas juga kerap pula bersikap kritis akan pandangan dan pendekatannya dalam penyampaiannya.

Dalam realitas pluralisme yang ada di Indonesia juga mempengaruhi terjadinya relativisme di dalam hidup masyarakat majemuk.Pluralisme menjadikan orang tidak teguh mempertahankan kebenaran yang dimilikinya. Kecenderungan ini terjadi tidak saja dalam teologi agama-agama, tetapi juga dalam pendekatan teologis yang memberi tekanan akan aspek Kerajaan Allah, dan menanggalkan aspek ekklesiosentris, kristosentris, dan teosentris. Situasi inilah yang terjadi di dalam diri saudara-saudara kita yang beragama Kristen (non-katolik), yang memahami bagian per bagian teologi dan ajaran Gereja. Pendekatan ini, sebagaimana diuraikan oleh Krispurwana Cahyadi mengutip Josep Ratzinger, tidak akan mendorong ke arah dialog sejati sebab tidak termuat lagi di dalamnya keperbedaaan dan keunikan kebenaran yang dimiliki, segalanya direlatifkan. ${ }^{18}$ Dogma pun mengalami proses relativisme. Dialog dalam realitas pluralisme diharapkan jangan sampai mengorbankan kebenaran dasar bahwa kebenaran iman mengakar pada Pribadi Yesus Kristus.

Gereja Katolik yang diwartakan oleh katolisitas adalah Gereja yang hendak setia pada kebenaran, bukan dalam sikap kompromi, bukan dalam sikap mengikuti arus 
zaman yang bisa menjauhkan Gereja dari kesetiaannya akan kebenaran Kristus. Memang Gereja itu adalah Gereja yang terbuka akan berbagai hal nyata yang ada dalam masyarakat, akan tetapi keterbukaan itu adalah keterbukaan dialogis, dalam prinsip Gereja bersikap tegas, namun keterbukaan yang menyeret pada sikap relativistik Gereja menolak. Oleh karena itu, sikap katolisitas dalam menanggapi pelbagai macam hal, terutama fenomena permasalahan zaman modern ini, katolisitas tidak mau terjebak dalam kecenderungan individualistik, gejala yang menempatkan diri sendiri sebagai ukuran penilaian, dan memutlakkan pandangan pribadi. Katolisitas adalah sarana pewartaan iman Kristiani yang berusaha setia pada Gereja Katolik, yang merupakan Gereja yang bersama, dalam kesetiaan pada prinsip penggembalaan Gerejani, menapaki ziarah di tengah arus zaman, dan sekaligus dalam perjalanan ziarahnya itu memberikan kesaksian akan kebenaran, kebenaran yang hanya bisa ditemukan dalam diri Yesus Kristus, Putera Allah yang hidup. Berikut kami tampilkan hasil penelitian dalam tabel 5 mengenai komunikasi yang menggali dasar \& kebenaran iman berhadapan dengan tantangan arus zaman modern:

\section{Tabel 3}

Dialog yang Menggali Dasar \& Kebenaran Iman serta Setia pada Kebenaran itu berhadapan dengan Tantangan Arus Zaman Modern

\begin{tabular}{|c|c|c|}
\hline \multicolumn{2}{|c|}{ Dialog yang Menggali Dasar \& } & \\
$\begin{array}{c}\text { Kebenaran Iman serta Setia pada } \\
\text { Kebenaran itu berhadapan dengan } \\
\text { Tantangan Zaman }\end{array}$ & \\
\cline { 1 - 2 } $\begin{array}{c}\text { Member \& Tim } \\
\text { katolisitas yg } \\
\text { melakukannya \& } \\
\text { setia pada } \\
\text { kebenaran }\end{array}$ & $\begin{array}{c}\text { Member jatuh pd } \\
\text { kecenderungan } \\
\text { individualistik \& } \\
\text { memutlakkan } \\
\text { pandangan } \\
\text { pribadi }\end{array}$ & Total \\
\hline 1415 & 389 & 1804 \\
\hline $78,43 \%$ & $21,57 \%$ & $100 \%$ \\
\hline
\end{tabular}

Lebih dari tiga perempat member dan pengasuh katolisitas $(78,42 \%)$ berani menggali kebenaran dalam Yesus Kristus dan berani setia pada ajaran kebenaran itu berhadapan dengan tantangan arus zaman modern dan perkembangannya. Mereka tetap bersikap terbuka, namun memegang teguh pada prinsip kebenaran yang mutlak dan tidak jatuh pada sikap relativistik. Contoh komentar yang muncul terhadap para pengasuh katolisitas yang menekankan pada dialog yang menggali dasar dan kebenaran iman serta setia pada kebenaran itu berhadapan dengan tantangan arus zaman modern:

Trima kasih Ibu Ingrid atas penjelasannya, semoga sebagai umat Katolik, iman kita dikuatkan sehingga mampu menjawab pertanyaan-pertanyaan / tuduhan dari orang lain dengan penuh kasih serta memperoleh bimbingan dari Roh Kudus (Valen dalam "Satanisme dlm Gereja Katolik” pada 21 Juni 2010 @ 6:29 am)

Sedangkan kurang dari seperempat member $(21,58 \%)$ akhirnya terjebak dalam kecenderungan individualistik, gejala yang menempatkan diri sendiri sebagai ukuran penilaian, dan memutlakkan pandangan pribadi. Mereka inilah yang mencoba menganalisis ajaran Gereja Katolik bagian per bagian dan melihat Kitab Suci hanya sebagai rumus dan melihat Kitab Suci dan teologi dalam potongan historis tanpa mengenal keseluruhan perjalanan historisitas tradisi di dalamnya.

\section{REFLEKSI TEOLOGIS DARI HASIL PENELITIAN}

\section{Keterlibatan Katolisitas untuk Menyiarkan Kabar Keselamatan bagi Semua Bangsa}

Gereja mengemban tugas meyiarkan iman serta keselamatan Kristus yang diwariskan kepada para Rasul dan dilanjutkan kepada pengganti Petrus serta Gembala Tertinggi Gereja lalu diteruskan Dewan para Uskup yang dibantu oleh para imam dan kepada para anggota Gereja, dengan daya-kekuatan kehidupan ikut menerima perutusan untuk mewartakan iman serta keselamatan kepada semua makhluk. ${ }^{19}$ Yesus Kristus sendirilah yang mengutus: "Pergilah, jadikanlah semua bangsa murid-Ku dan baptislah mereka dalam nama Bapa dan Anak dan Roh Kudus" (Mat 28:19). Dengan demikian, Gereja dipanggil dan diutus untuk 
melanjutkan komunikasi Allah Tritunggal dalam pewahyuan dan penjelmaan yang sesuai dengan konteks dan budaya setempat pada masa kini dan di sini.Gereja dilahirkan dalam tindak komunikasi Allah Roh Kudus pada hari Pentakosta. ${ }^{20}$ Roh yang sama ini mengubah para murid yang ketakutan menjadi pewarta yang gagah berani. Setiap orang yang datang dari segala penjuru bumi memahami bahasa mereka. Seperti dikatakan Konsili Vatikan II dalam dokumen tentang misi Ad Gentes: "Pada hakikatnya Gereja peziarah bersifat misioner, sebab berasal dari perutusan Putera dan perutusan Roh Kudus menurut rencana Allah Bapa. Adapun rencana itu bersumber pada cinta atau kasih asali Allah Bapa; dari Dialah Putera lahir dan Roh Kudus berasal dari Putera"(Ad Gentes art. 2).

Peristiwa Pentakosta selanjutnya merupakan contoh yang sangat mengesankan tentang komunikasi antar-budaya, komunikasi kedatangan Allah kepada semua bangsa dari segala kebudayaan pada zaman itu - dalam satu bahasa dan dalam satu kesempatan. Setelah peristiwa Pentakosta, para murid Kristus melaksanakan misi dan perutusan Kristus untuk mewartakan Kabar Sukacita Allah kepada manusia hingga akhir zaman. Pewahyuan dan penjelmaan bermuara dalam Gereja (sejauh Gereja menjadi tubuh Kristus, dan Kristus sebagai kepalanya) sebagai kelanjutan komunikasi diri Allah hingga akhir zaman. Gereja ini bermula dengan kedatangan Roh Kudus pada hari Pentakosta dan senantiasa dituntun oleh Roh Kudus sebagai "pelaku komunikasi diri Allah". Komunikasi diri Allah yang terus-menerus melalui Gereja ini terutama sekali diungkapkan dalam kehidupan berserta fungsi Gereja sebagai sebagaipewarta (kerygma) dan sebagai persekutuan (koinonia).

Dalam tugas perutusan Kristus kepada para murid-Nya yaitu Gereja, para murid Kristus yang tergabung dalam website Katolisitas yang juga bagian dari Gereja, memiliki tanggung jawab dan partisipasi aktif untuk mewartakan Kabar Sukacita yang berasal dari Kristus itu kepada dunia melalui media komunikasi sosial yaitu internet. Menurut penulis, partisipasi aktif yang dilakukan oleh website Katolisitas di dunia internet memiliki pengaruh yang besar bagi umat Katolik (maupun nonkatolik) untuk menyiarkan tentang ajaran Kristus kepada dunia. Apalagi dalam konteks Indonesia, hingga saat ini, baru website Katolisitas yang secara serius dan total menangani website rohani Katolik yang menyediakan ajaran dan iman Katolik yang lengkap, komprehensif, sistematis dan dapat dipertanggungjawabkan ajarannya berdasarkan pada Kitab Suci, Magisterium Gereja, dokumen-dokumen resmi Gereja dan hirarki Gereja. Website katolisitas ini juga memiliki tim kerja yang memang solid dan selalu berada pada koridor ajaran Gereja Katolik karena timnya terdiri dari para awam yang ahli di bidangnya (pendiri sekaligus pengasuh utamanya juga ahli teologi), beberapa imam Gereja Katolik yang terlibat dan menjadi pembimbing katolisitas dengan setia, serta biarawan-biarawan yang turut mendukung karya pelayanan ini dalam bentuk pelayanan doa yang juga tersedia di kolom pojok doa di katolisitas.

Di bawah bimbingan beberapa imam atau hirarki Gereja, ajaran-ajaran yang diwartakan di website Katolisitas memang dapat dipertanggungjawabkan kebenarannya sesuai dengan ajaran dan iman Gereja Katolik. Melalui website Katolisitas itu, para murid Kristus yang merupakan bagian dari anggota Gereja, melakukan tugas perutusan Kristus untuk mewartakan Kabar Sukacita itu di dalam dunia internet dan melakukannya secara maksimal dan berkesinambungan. Maksudnya, melalui website Katolisitas, umat Katolik juga dapat menjalin dialog dan diskursus iman yang mendalam dan terbentuk persekutuan yang saling meneguhkan melalui forum tanyajawab di Katolisitas. Di sinilah peran awam dan para Gembala menjadi sinergis, dan ini dituangkan dalam Dekrit Inter Mirifica art. 13 paragraf 2 yang mengatakan:

Hendaklah para Gembala dibidang itu pun dengan tangkas menunaikan tugas mereka, karena tugas itu berhubungan erat dengan kebajiban harian mereka mewartakan Injil. Para awam pun yang berperan dalam penggunaan media itu, hendaknya berusaha memberi kesaksian tentang Kristus, terutama dengan menunaikan tugas mereka masing-masing penuh keahlian dan berjiwa kerasulan; 
bahkan juga dengan secara langsung menyumbangkan jasa-jasa mereka dibidang tehnik, ekonomi, kebudayaan dan kesenian bagi kegiatan pastoral Gereja, sesuai dengan posisi mereka. ${ }^{21}$

Gereja harus hadir di tengah golongangolongan manusia itu melalui putera-puteranya, yang diam di antara mereka atau diutus kepada mereka. Sebab segenap umat beriman kristiani, dimana pun mereka hidup, melalui teladan hidup serta kesaksian lisan mereka wajib menampilkan manusia baru, yang telah mereka kenakan ketika dibaptis, maupun kekuatan Roh Kudus, yang telah meneguhkan mereka melalui sakramen Krisma. Dengan demikian sesama akan memandang perbuatan-perbuatan mereka dan memuliakan Bapa (lih. Mat 5:16), dan akan lebih penuh menangkap makna sejati hidup manusia serta ikatan persekutuan semesta umat manusia ( $A d$ Gentes art. 11 paragraf 1).

Melihat perutusan Gereja kepada para anggotanya (dalam hal ini para awam), penulis melihat sisi kontekstualisasi dan aktualisasi diri Gereja ini tampak nyata hadir dalam diri katolisitas itu sendiri. Jika melihat gaya hidup dan budaya yang berkembang pada masa kini yang diwarnai oleh hadirnya informasi yang begitu deras melalui adanya internet, maka katolisitas dengan tim hadir menawarkan suatu pendekatan yang baru yang sesuai dengan konteks masyarakat zaman modern ini. Katolisitas hadir bukan hanya memberi informasi saja, melainkan turut mengajak pembacanya untuk mendalami pengetahuan iman dan ajaran Gereja secara utuh dan komprehensif serta berdasarkan dari sumber yang terpercaya, seperti dari: Kitab Suci, Magisterium Gereja, dan, Dokumen-dokumen resmi Gereja. Katolisitas berupaya untuk menyapa para pembacanya untuk terbuka dan mengungkapkan gagasannya, lalu kemudian mendalaminya untuk mencapai suatu kebenaran dalam Kristus.

Sisi kehadiran katolisitas di tengahtengah kehidupan para pembacanya ini, setelah melihat hasil penelitian yang dipaparkan di bagian sebelumnya, tampil dalam segi kontinuitas para pengasuh katolisitas dalam menanggapi para pembaca dan dilakukan beberapa kali sehingga komunikasi- nya pun tidak terputus. Kehadiran itu juga tampak dalam keramahan yang mereka tampilkan dalam dialog dan penghargaan mereka akan gagasan yang diungkapkan oleh para pembaca. Sisi kontinuitas, keramahan, dan penghargaan inilah yang menjadi warna kekhasan tersendiri dari bentuk karya pewartaan yang baru ini, yang berbeda dengan yang lain. Ciri khas inilah yang juga tertuang dalam $A d$ Gentes art 11 paragraf 2:

Supaya kesaksian mereka akan Kristus itu dapat memperbuahkan hasil, hendaklah mereka dengan penghargaan dan cinta kasih menggabungkan diri dengan sesama, menyadari diri sebagai anggota masyrakat di lingkungan mereka, dan ikut serta dalam kehidupan budaya dan sosial melalui aneka cara pergaulan hidup manusiawi dan pelbagai kegiatan. Hendaknya mereka sungguh mengerti tradisi-tradisi kebangsaan dan keagamaan mereka, dan dengan gembira serta penuh hormat menggali benih-benih Sabda yang terpendam di situ. Tetapi sekaligus hendaknya mereka memperhatikan proses perubahan mendalam, yang sedang berlangsung pada bangsa-bangsa itu, dan ikut mengusahakan, supaya orang-orang zaman sekarang jangan terlampau memperhatikan ilmu-pengetahuan serta teknologi dunia modern, sehingga terasingkan dari nilai-nilai ilahi, bahkan supaya mereka dibangkitkan untuk semakin intensif merindukan kebenaran dan cinta kasih yang diwahyukan oleh Allah. Kristus sendiri menyelami hati sesama-Nya dan melalui percakapan yang sungguh manusiawi menghantar mereka kepada terang ilahi. Begitu pula hendaklah para murid-Nya, yang secara mendalam diresapi oleh Roh Kristus, memahami sesama dilingkungan mereka dan bergaul dengan mereka, sehingga berkat dialog yang jujur dan sabar itu mereka makin mengetahui, hartakekayaan manakah yang oleh Allah dalam kemurahan-Nya telah dibagikan kepada para bangsa. Serta merta hendaklah mereka berusaha menilai kekayaan itu dalam cahaya Injil, membebaskannya, dan mengembalikannya kepada kekuasaan Allah Penyelamat. ${ }^{22}$

Katolisitas berusaha dalam karya pelayanannya untuk menyelami hati sesamanya dan melalui dialog yang sungguh manusiawi akhirnya menghantar para pembacanya 
kepada terang ilahi, Kristus sendiri. Kenyataan itu tampak dalam beberapa dialog yang diungkapkan oleh para pembaca, seperti contoh berikut:

\begin{abstract}
Mohon ijin kepada admin. Saya ingin mengajak kepada seluruh umat Katolik yang menemukan website Katolisitas ini, marilah kita menyebarkan website ini kepada saudara-saudara kita yang lainnya. Ini sangat berguna bagi kita, terlebih untuk meneguhkan iman dan juga untuk mempertanggungjawab kannya. Saya salut, website ini sungguh membantu saya agar semakin dewasa dalam hal iman. (Flotamardlm Mengapa guncang mendengar wahyu-wahyu pribadi yang memojokkan Gereja Katolik pada 18 Juni 2011 @ 11:10 pm)
\end{abstract}

Saya sangat bersyukur menemukan website ini karena menambah pengetahuan dan juga membantu memperkuat iman Katolik saya. (Lambertus Hermawan dalam Kriteria org diberi gelar santo/a pada 13 Agust2012@ 5:10 am)

Demikianlah gambaran segala upaya yang dilakukan website katolisitas dalam menghayati pewartaan dalam media pewartaan yang baru yaitu internet, dan mereka berupaya semaksimal mungkin untuk hidup di tengah-tengah umat modern dan terlibat aktif dalam segala aspek kehidupan sekaligus dalam suka-duka kehidupan orang modern.

\section{Di dalam Kristus Katolisitas Ikut Menjadi Tanda Keselamatan Allah kepada Dunia Kini dan di Sini}

Dalam kesatuannya dengan Kristus dalam Gereja, website Katolisitas berupaya menekankan agar kesatuan dalam iman akan Kristus itu tetap terwujud dalam praktek kehidupan orang beriman. Wujud dari realisasi akan kesatuan itu diungkapkan melalui pencarian akan kebenaran dalam Diri Kristus sebagai pewahyuan Diri Allah yang tampak bagi manusia. Melalui dialog dan tanya-jawab dalam ruang yang telah disediakan oleh Katolisitas, tim Katolisitas berusaha agar para pembaca dapat diterangi oleh Cahaya Kebenaran yang berasal dari Kristus itu dan akhirnya percaya kepada Kristus dengan kepenuhan akal budi berkat pencerahan dari Roh
Kudus. Pada tahap ini, orang diajak untuk beriman kepada Kristus secara sadar dan terbuka berdasarkan pada pendasaran rasional (Fides querens intellectum) dalam pencariannya akan kebenaran sejati dalam hidup. Dalam proses pencarian akan kebenaran itu, para member/ pembaca yang tergabung di Katolisitas berusaha mengungkap 'misteri' yang mengarah pada segi-segi realita Kehendak Allah yang tampak dalam ajaran-ajaran Gereja dan iman Gereja. Kehendak Allah itu terwadahi dalam Kitab Suci, Ajaran-ajaran Gereja, tradisi Gereja, Magisterium dan apa yang diimani oleh Gereja sehingga melaluinya para member/ pembaca diajak untuk memahami Kehendak Allah melalui Gereja-Nya.

Gereja merupakan tanda dan alat keselamatan, hal ini menunjukkan bahwa Gereja, dari satu pihak, adalah realisasi kini dari keselamatan dan di pihak lain, Gereja merupakan realisasi dalam pengharapan. Sebagai realisasi kini dari Keselamatan, Gereja hic et nunc sudah menyatakan dan melaksanakan keselamatan itu kini dan di sini. Website Katolisitas dalam kesatuan dengan Kristus dan Gereja, menyiarkan bahwa Kerajaan Allah sudah datang sekarang. Dalam komunikasi iman yang terjadi di katolisitas, misteri kebenaran Sabda Allah mendapatkan dimensi aktualnya, yaitu dengan penjelasan yang terang dan menghantar pembaca untuk menemukan kebenaran dalam Kristus melalui ajaran Gereja yang diwartakan di katolisitas, yang bisa diakses dengan mudah oleh siapa pun, kapan pun, dan di mana pun, kini dan di sini (hic et nunc). Di sini pembaca diajak untuk tidak berjalan dalam kegelapan lagi (bahasa komunikasinya: ketidaktahuan dan minimnya informasi), tetapi pembaca dihantar melalui dialog menuju pada cahaya terang Ilahi yang sudah mulai bersinar dalam Yesus Kristus. Keterlibatan katolisitas dalam mewartakan Warta Keselamatan dalam Kristus yang terjadi kini dan disini, juga termuat di dalam Dekrit Inter Mirifica art. 3:

Gereja katolik didirikan oleh Kristus Tuhan demi keselamatan semua orang; maka merasa terdorong oleh kewajiban untuk mewartakan Injil. Karena itulah Gereja memandang sebagai kewajiban- 
nya, untuk juga dengan memanfaatkan media komunikasi sosial menyiarkan Warta Keselamatan, dan mengajarkannya, bagaimana manusia dapat memakai media itu dengan tepat. Maka pada hakikatnya Gereja berhak menggunakan dan memiliki semua jenis media itu, sejauh diperlukannya atau berguna bagi pendidikan kristen dan bagi seluruh karyanya demi keselamatan manusia. ${ }^{23}$

Hal itu diupayakan oleh Katolisitas dalam pencarian akan Kristus sebagai kebenaran sejati dalam ajaran-Nya yang diturunkan kepada para rasul, para murid dan kini kepada Gereja-Nya. Jadi ketika orang beriman, khususnya para member dan pembaca, dilibatkan untuk berkomunikasi dan terbuka dalam dialog iman, orang diajak untuk meninggalkan kegelapan akan imannya yang selama ini "tidur" itu kepada terang ilahi yang berasal dari Yesus yang dikenal melalui ajaran-Nya. Kerajaan Allah atau keselamatan tidak hanya dimaklumkan Gereja, tetapi juga tampak dalam buahbuah hasilnya dan pertanda hadiratnya sudah mulai terealisir. Misalnya: Pewartaan Sabda menghasilkan keterbukaan "mata iman" para member atau pembaca yang menghantar pada iman yang semakin teguh dan membawa pada hidup yang penuh perdamaian dan pertobatan. Lebih dari setengah member $(67,43 \%)$ dan pembaca Katolisitas yang merasa dikuatkan dan diteguhkan imannya melalui diskusi iman, pengajaran iman dan sharing iman yang terjadi di ruang tanya-jawab Katolisitas. Kesadaran akan kedewasaan iman, yang disadari setelah menerima pencerahan iman, mengangkatnya secara riil dalam Umat Allah yang terlibat dengan dunia, di mana manusia lama dikuburkan dan manusia baru dibangkitkan. Dari sana umat mulai tergerak dalam pelayanan Gereja dan juga pelayanan sosial karena dibimbing dan dibantu oleh kurnia-kurnia Roh Kudus, teristimewa kurnia Roh Cintakasih. Janjijanji dan tanda-tanda berkuasanya Kerajaan Allah sudah tampak nyata dalam Gereja. Melalui pengabdian Gereja kepada masyarakat dunia, Allah dalam Kristus sedang berdaulat dalam dunia ini sebagai seorang raja yang mengabdi dan menyelenggarakan masyarakat. Dalam pengabdian terhadap Gereja dan di dalam Kristus, Katolisitas berusaha untuk mengabdi kepada umat beriman dan masyarakat luas agar terciptalah persatuan dan perdamaian karena mata semua orang bisa terbuka dari kegelapan dosa dan dapat melihat terang yang membuka hati semua orang untuk melihat Sang Cahaya dan Kebenaran sejati yaitu Kristus.

\section{Mewartakan Kristus dalam Realitas Medan Kehidupan}

Gereja telah ditugaskan untuk mewariskan pewartaan Kerajaan Allah kepada dunia dan dari sanalah pelaksanaan tugas luhur yang diberikan Kristus harus aktualisasi yang nyata dalam dunia hingga pada masa kini. Gereja diumpamakan sebagai utusan seorang raja yang datang ke tempat umum untuk memaklumkan sebuah dekrit raja. Secara radikal model eklesiologi ini dipusatkan pada Kristus dan Kitab Suci sebagai saksi utama tentang Kristus. Karena itu tugas pokok Gereja adalah mewartakan Kristus. Pandangan tentang eklesiologi ini dengan baik sekali dirumuskan oleh Richard McBrien sebagaimana diuraikan oleh Eilers sebagai berikut:

"Misi Gereja adalah mewartakan Sabda Allah ke seluruh dunia. Gereja tidak perlu menganggap diri bertanggung jawab bila orang tidak menerimanya sebagai Sabda Allah, namun Gereja harus mewartakan Sabda itu dengan jujur dan tekun. Semua yang lain bersifat sekunder belaka. Menurut hakikatnya Gereja merupakan satu komunitas kerygmatis yang melalui Sabda yang diwartakan tetap mengenangkan perbuatan-perbuatan Allah yang mengagumkan dalam sejarah manusia, teristimewa perbuatan-perbuatan-Nya yang berkuasa dalam diri Yesus Kristus. Komunitas itu terbentuk di mana saja dengan daya kekuatan Roh Kudus yang berhembus, di mana saja Sabda Allah diwartakan dan diterima dalam keteguhan iman. Maka Gereja itu merupakan peristiwa, suatu tempat pertemuan antara manusia dengan Allah dan antara manusia dengan sesamanya dalam keterarahan kepada Allah". ${ }^{24}$

Dalam peranannya sebagai peristiwa medan pertemuan antara manusia dengan Allah, manusia-manusia yang menuju pada Allah- Gereja harus membangun komuni- 
kasi sebagai dasar dengan dunia secara umum dan harus berani keluar untuk berkomunikasi dengan siapa saja termasuk dengan aneka kebudayaan yang menyertai sejarah hidup manusia untuk dapat mengaktulisasikan secara nyata Kabar Gembira dalam Kristus itu. Dalam Gaudium et Spes juga tercantum amanat yang menekankan pentingnya Warta Gembira tentang Kristus itu harus menyapa kebudayaan manusia.

Sebab Allah, yang mewahyukan Dirinya sepenuhnya dalam Putera-Nya yang menjelma, telah bersabda menurut kebudayaan yang khas bagi pelbagai zaman. Begitu pula Gereja, yang di sepanjang zaman hidup dalam pelbagai situasi, telah memanfaatkan sumber-sumber aneka budaya, untuk melalui pewartaannya menyebarluaskan dan menguraikan pewartaan Kristus kepada semua bangsa, untuk menggali dan makin menyelaminya, serta untuk mengungkapkannya secara lebih baik dalam perayaan liturgi dan dalam kehidupan jemaat beriman yang beranekaragam. ${ }^{25}$

Gereja dalam dirinya sendiri merupakan sebuah kehidupan beserta dengan budaya yang menyertai kehidupan manusia, di mana komunikasi harus terus-menerus hidup dan terjadi dalam himpunan umat beriman. Sebab Gereja adalah sebuah masyarakat komunikasi yang universal dan tak terbatas (universale Kommunikationsgemeinschaft) ungkapan yang dipakai Helmut Peukert, seperti dikutip oleh G. P. Sindhunata ${ }^{26}$ Sebab itu, Gereja senantiasa terbuka kepada segala bentuk budaya yang ada di dalam sejarah kehidupan manusia, tanpa bersifat eksklusif dengan budaya mana pun, dan ini tertuang dalam Gaudium et Spes art. 58 paragraf 3:

Gereja yang diutus kepada semua bangsa dari segala zaman dan di daerah mana pun, tidak terikat secara eksklusif tak terceraikan kepada suku atau bangsa mana pun, kepada corak hidup yang khas mana pun, kepada adat istiadat entah yang lama entah yang baru. Seraya berpegang teguh pada tradisinya sendiri, pun sekaligus menyadari perutusannya yang universal, Gereja mampu menjalin persekutuan dengan pelbagai pola kebudayaan.

Gereja harus terus mengadakan tindakan-tindakan komunikasi di tengah kebu- dayaan manusia. Dan dengan mempraktikkan tindakan komunikatif ini, Gereja akan menyingkapkan keselamatan-keselamatan dalam realitas yang dihadapinya dan dijumpainya. Dengan tindakan tersebut, Gereja sendiri akan mengungkapkan keselamatan, dan menjadi sebuah universale Kommunikations gemeinschaft yang menyelamatkan pula.

Agar dapat menjadi universale Kommunikationsgemeinschaft, Gereja kiranya perlu mengubah gaya dan cara pewartaan Kabar Gembiranya. Di sini kita perlu kembali ke pesan pertanyaan Paulus: Bagaimana mereka dapat percaya kepada Dia, jika mereka tidak mendengar tentang Dia? Bagaimana mereka dapat mendengar tentang Dia, jika tidak ada yang memberitakanNya? Dan bagaimana mereka dapat memberitakan-Nya, jika mereka tidak diutus? (Rom 10:14). ${ }^{27}$ Maka itu pewartaan Kabar Gembira harus bisa menjangkau semua orang. Artinya, Kabar Baik itu harus juga dirasakan oleh orang yang bukan Kristiani dalam kehidupan harian yang terjadi di medan profan, yaitu di lingkungan pekerjaan, sekolah atau kampus, lingkungan masyarakat, dan lingkungan media cetak, elektronik dan media internet. Di sana diandaikan terjadi keterlibatan yang sinergi antara pejabat Gereja dan kaum awam, dan kaum awam mempunyai potensi, kemampuan dan talenta yang lebih banyak di dalam medan pewartaan profan tersebut.

Pewartaan keluar ini mempunyai wajah yang lain dengan pewartaan ke dalam, yang biasanya dipercayakan pada fungsionaris resmi gerejani. Maksudnya, pewartaan itu membutuhkan bahasa lain dengan yang biasanya dipakai pewartaan "ke dalam" atau "di dalam" Gereja. Selain itu, pewartaan keluar ini membutuhkan hal yang lebih hakiki, yakni keberanian dan ketekunan. Tugas pewartaan keluar itu sudah dilaksanakan oleh website Katolisitas di medan yang profan yaitu media internet. Di media internet yang profan itu, Katolisitas menjangkau orang-orang beriman Katolik dan juga orang-orang non-katolik yang ingin mengetahui kebenaran iman Katolik. Katolisitas beserta timnya berupaya mengambil tugas pewartaan keluar itu berangkat dari omong-omong, pekerjaan harian dan peris- 
tiwa-peristiwa yang sifatnya amat dekat dengan kehidupan masyarakat luas yang nyata dan up to date. Justru dari fenomena terkini yang terjadi di dalam kehidupan masyarakat, mereka (Katolisitas) mulai membangun diskusi dan dialog iman yang nyata dan saling berbagi pengetahuan dan pengalaman iman untuk mencari kebenaran hakiki dalam hidup. Ruang dialog dan diskusi ini juga tersedia bagi siapa pun yang berniat untuk mencari kebenaran dalam iman Katolik, dan ada lebih dari sepertiga member Katolisitas (37,73\%) yang berasal dari orang non-katolik yang ikut terlibat dalam dialog dan diskusi di ruang yang telah disediakan. Melalui ruang dialog itulah katolisitas membangun sebuah masyarakat komunikasi yang universal dan tak terbatas (universale Kommunikationsgemeinschaft).

Dalam media internet yang amat berbeda dengan "lingkaran Gerejani", tentu suatu bentuk pewartaan mendapatkan bentuk aktualisasi yang nyata dan bisa menjangkau orang-orang di luar lingkungan Gerejani. "Bahasa baru" yang digunakan dalam bentuk gambar, simbol, petikan katakata inspirasi, audio atau video menjadi bahasa yang sangat efektif dalam mewartakan Kabar Keselamatan. "Bahasa baru" dalam bentuk kreatifitas ini menjadi salah satu bahan yang dipakai oleh Katolisitas untuk mewartakan Kabar Keselamatan itu. Dari sana kemudian, orang diajak untuk mencari kebenaran dan diajak untuk meninggalkan kegelapan menuju kepada kebenaran sejati dalam Kristus. Dalam pencarian itulah terjadi sebuah masyarakat komunikasi yang universal dan tak terbatas atau universale Kommunikationsgemeinschaft. Saat terjalin dialog dan diskusi iman di ruang tanya-jawab Katolisitas saat itulah Gereja berusaha mengungkapkan keselamatan, dan menjadi sebuah universale Kommunikationsgemeinschaft yang menyelamatkan pula.

\section{KESIMPULAN}

Perkembangan ilmu pengetahuan dan teknologi yang begitu pesat pada masa dewasa ini mengantarkan manusia pada suatu kemajuan kehidupan di berbagai bidang khususnya pada sektor industri, kesehatan, teknologi informasi dan kemajuan di bidang ekonomi dan sosial. Dengan bantuan perkembangan ilmu pengetahuan dan teknologi semua pekerjaan dan aktifitas manusia menjadi dipermudah. Dampak dari kemajuan tersebut sangat berpengaruh untuk meningkatkan sektor perindustrian dan membuka banyak kesempatan lapangan pekerjaan serta membantu meningkatkan kehidupan perekonomian suatu tempat atau daerah. Namun dampak itu baru bisa dirasakan di kota-kota besar, seperti Jakarta, Surabaya, Semarang, dan Bandung. Kemajuan itu belum merata dan menyeluruh ke setiap daerah di Indonesia. Maka, orang berbondong-bondong pergi ke kota besar untuk bisa mendapatkan pekerjaan yang layak dan upah yang layak.

Kehidupan orang modern di tengah kemajuan tersebut dituntut untuk bersaing guna mendapatkan kehidupan yang layak di kota besar. Kebanyakan orang modern mengisi waktunya untuk bekerja, bekerja dan bekerja agar dapat bersaing dengan yang lain dan dapat mencukupi kehidupan keluarganya. Kesibukan inilah yang menjadi panorama harian kehidupan orang modern di kota besar, seperti Jakarta. Belum lagi masalah-masalah lain yang ikut mewarnai kehidupan masyarakatnya yang heterogen dan majemuk, seperti: kemacetan, sampah, banjir, padat penduduk, kriminalitas, polusi udara, kurangnya lahan hijau, dan lain sebagainya. Belum lagi dengan adanya kemajuan teknologi yang semakin canggih, menjadikan orang melihat sesamanya sejauh bermanfaat dan berguna bagi kemajuan hidup. Manusia akhirnya dipandang sejauh ia mempunyai kapabilitas dan kemampuannya untuk menghasilkan sesuatu. Pendek kata, manusia memandang sesamanya bukan sebagai subjek yang memiliki harkat dan martabat yang luhur, melainkan sebagai objek yang berfungsi sama dengan teknologi yang dapat bernilai jika menghasilkan sesuatu.

Berangkat dari situasi orang modern dan situasi kota Jakarta yang seperti itu, maka orang modern yang hidup di Jakarta atau di kota besar lainnya mengalami degradasi nilai (keluhuran martabat kemanusiaan) dan dirundung oleh kekeringan akan makna hidup serta kekeringan rohani. 
Di tahap inilah, orang modern membutuhkan oase yang menyujukkan hati, pikiran dan imannya yang dapat membawa hidupnya lebih bermakna dan beriman kokoh dalam mengarungi kehidupan pada masa kini. Namun, masalahnya adalah untuk bisa mendapatkan oase, nilai kehidupan (living values) dan kebenaran iman, orang terkendala oleh waktu dan kesibukan. Sebab mereka pergi ke tempat bekerja pada pagi hari dan pulang larut malam. Masalah kesibukan dan keterbatasan waktu inilah yang bisa dijawab oleh kehadiran website katolisitas yang menawarkan suatu penjabaran dari isi Kabar Keselamatan yang relevan dan aktual di tengah konteks zaman ini, serta tidak batasi oleh ruang dan waktu. Sisi kepraktisan dan kemudahan untuk mengases ajaran iman Katolik yang lengkap dan benar inilah yang menjadi keunggulan dari cara berkatekese di zaman modern ini. Katekese dengan cara kovensional dan tradisional yaitu dengan perjumpaan di ruang resmi semakin sulit dilaksanakan bagi orang modern yang hidup di kota besar mengingat kesibukan dan mobilitas mereka yang tinggi. Melalui penelitian yang dilakukan ini, penulis mendapatkan jawaban dari masalah yang muncul untuk ruang pewartaan iman Katolik bagi orang modern zaman ini. Keterbatasan waktu, kesibukan, dan mobilitas orang modern yang tinggi tidak menyulitkan mereka untuk beriman kepada Kristus secara sadar dan terbuka berdasarkan pada pendasaran rasional (fides querens intellectum) dalam pencariannya akan kebenaran sejati dalam Kristus. Di sinilah pentingnya Komunikasi Iman melalui diskursus iman di dunia digital perlu dilakukan pada zaman modern ini.

\section{Rafael Yohanes Kristianto}

Lulusan Magister Teologi, Universitas Sanata Dharma Yogyakarta; Berkarya sebagai Pastor di paroki St. Gabriel Pulogebang, Keuskupan Agung Jakarta Email: rafaelkristianto10@gmail.com

\section{CATATAN AKHIR}

Pesan Paus Benedictus XVI pada Hari Komunikasi Sosial Sedunia Ke-47.

2 Larry L. Barker, Communication (New Jersey: Prentice-Hall International, Inc., 1984), 5.
3 Lukas Batmomolin \& Fransiska Hermawan, Budaya Media: Bagaimana Pesona Media Elektronik Memperdaya Anda (Ende: Nusa Indah, 2003), 17-18

4 Lukas Batmomolin, Budaya Media, 24.

5 Nancy S. Love, dalam Stephen K. White (ed.), The Cambridge Companion to Habermas (New York: Cambridge University Press, 1995), 57.

6 Nancy S. Love, dalam Stephen, The Cambridge Companion to Habermas, 59-60.

7 Georgia Warnke, dalam Stephen K. White (ed.), The Cambridge Companion to Habermas (New York Cambridge University Press, 1995), 120-121.

8 Georgia Warnke, dalam Stephen, The Cambridge Companion to Habermas, 124-125.

9 Jürgen Habermas, "Historical Materialism and the Development of Normative Structure", dalam Communication and the Evolution of Society (Alih bahasa: Thomas McCarthy), (Boston: Beacon Press, 1979), 100.

10 Georgia Warnke, dalam Stephen K. W., The Cambridge Companion to Habermas, 138-139.

11 Patrick Granfield, The Church and Communication (Kansas City:Sheed\& Ward, 1994), 1.

12 Franz-Josef Eilers, Berkomunikasi dalam Pelayanan dan Misi (terj. Komsos KWI), (Yogyakarta: Kanisius, 2008), 11.

13 Franz-Josef Eilers, Communicating in Community: AnIntroduction to Social Communication(Manila: Logos Publication, 2002), 6.

14 Franz-Josef Eilers, Communicating in Community, 40-41.

15 Franz-Josef Eilers, Communicating in Community, 41-42.

16 Berhard Häring, Free and faithful in Christ. Moral Theology for Priests and Laity, Vol II: The Truth Will Set You Free (London: St. Paul, 1979), 46.

17 Krispurwana Cahyadi, SJ, Banediktus XVI (Yogyakarta: Kanisius, 2010), 415.

18 Krispurwana Cahyadi, Banediktus XVI, 417.

19 Ad Gentes art. 5.

20 Franz-Josef Eilers, Berkomunikasi dalam Pelayanan, 29.

21 Inter Mirifica art. 13

22 Ad Gentes art.11.

23 Inter Mirifica art. 3.

24 Franz-Josef Eilers, Berkomunikasi dalam Pelayanan dan Misi, 73.

25 Gaudium et Spes art. 58.

26 G. P. Sindhunata, Garam yang kurang asinnya (Tulisan untuk rekoleksi imam-imam KAS, 25-26 Maret 2013), (Yogyakarta 2013), 25.

27 G. P. Sindhunata, Garam yang kurang asinnya, 26.

\section{DAFTAR RUJUKAN}

Barker, Larry L. Communication. New Jersey: Prentice-Hall International, Inc, 1984. 
Batmomolin, Lukas \& Fransiska Hermawan. Budaya Media: Bagaimana Pesona Media Elektronik Memperdaya Anda. Ende: Nusa Indah, 2003.

Eilers, Franz-Josef. Berkomunikasi dalam Pelayanan dan Misi. (terj. Komsos KWI) Yogyakarta: Kanisius, 2008.

Eilers, Franz-Josef. Communicating in Community: An Introduction to Social Communication. Manila: Logos Publication, 2002.

George, Susan Ella. Religion and Technology in the $21^{\text {st }}$ Century: Faith in The E-world. Harshey, U.S.A: Information Science Publishing, 2006.

Habermas, Jürgen. Moral Consciousness and Communicative Action (Alih bahasa: Christian Lenhardt and Shierry Webber N.). Cambridge: Polity Press, 1990.
Habermas, Jürgen. Communication and the Evolution of Society (Alih bahasa: Thomas McCarthy). Boston: Beacon Press, 1979.

Häring, Berhard. Free and faithful in Christ. Moral Theology for Priests and Laity. Vol II: The Truth Will Set You Free, London: St. Paul, 1979.

Sindhunata, G. P. Garam yang Kurang Asinnya (Tulisan untuk rekoleksi imam-imam KAS, 25-26 Maret 2013), Yogyakarta, 2013.

Smith, James K.A. (ed.). What Would Jesus Deconstruct? The Good News of Postmodernism for The Church. Michigan: Baker Academic, 2007.

White, Stephen K., (ed.). The Cambridge Companion to Habermas. New York: Cambridge University Press, 1995. 